BIOMEDICAL AND BIOSOCIAL ANTHROPOLOGY
Official Journal of the International Academy
of Integrative Anthropology
journal homepage: http://bba-journal.com

\title{
Sexual features of spirometric indices within the juvenile period of ontogenesis
}

Kyrychenko Yu. V. ${ }^{1}$, Sarafinyuk L. A. ${ }^{1}$, Sarafinyuk P. V. ${ }^{2}$, Romanenko O. I. ${ }^{1}$, Lischyshyn G. B. ${ }^{1}$

${ }^{1}$ National Pirogov Memorial Medical University, Vinnytsya, Ukraine

${ }^{2}$ Vinnitsa State Pedagogical University named after Mikhail Kotsyubinsky, Vinnytsya, Ukraine

\section{ARTICLE INFO}

Received: 27 December 2018

Accepted: 28 January 2019

UDC: $57.017 .642: 616-053.7$

CORRESPONDING AUTHOR

e-mail: kyrychenkoyura@gmail.com Kyrychenko Yu. V.

\begin{abstract}
The factor of sexual dimorphism is dominant in the ontogenetic formation of various organs and systems, in particular the respiratory organs, whose morpho-functional indicators have significant sex differences. The aim of this work is to establish the sex characteristics of spirographic normative indices in practically healthy young men and young women within the juvenile ontogeny period. Spirographic examination of 109 young women of the ontogeny adolescence was performed, including: 17-year-olds 29; 18-year-olds - 27; 19-year-olds - 25; 20-year-olds - 28 people and 124 young men, including: 17-year-olds - 28; 18-year-olds - 37; 19-year-olds - 27; 20-year-olds - 32 people. Spirographic examination was performed according to the method of the American Association of Pulmonologists (1995) on the device Medgraphics Pulmonary Function System 1070 series. The analysis of the obtained results was carried out with the help of the licensing program "Statistica 5.5" using non-parametric methods of estimation of indicators. It is established that the indicators of vital capacity of lungs, forced vital capacity, forced capacity of lungs on inhalation, maximal voluntary ventilation, forced expiratory flow rate respectively of $25 \%$ of forced vital capacity, maximum peak expiratory flow, inspiratory capacity, expiratory reserve volume and one-second forced exhalation volume in young men each calendar year and the general group is significantly higher compared to the corresponding years of ontogeny in young women. The only spirometric indicator that is significantly higher for young women than for young men is the Tiffno Index. The revealed sex differences in the magnitude of spirometric parameters can be explained by the significant somatometric differences between the male and female body. Based on the results obtained, we can conclude that the vast majority of spirometric parameters in young men in all calendar periods of adolescence have higher rates than in young women. The most significant gender differences in the majority of spirometric parameters were identified in 18-year-olds.
\end{abstract}

Keywords: spirometry, spirometric indices, young men, young women, sexual dimorphism.

\section{Introduction}

The factor of sexual dimorphism is dominant in the ontogenetic formation of different organs and systems. In this area, there are studies related to the determination of the sex differences of cardiovascular and parenchymal organs $[8,16,18]$. There is no exception regarding the presence of signs of sexual dimorphism and respiratory organs, morphofunctional indicators of which have significant sex differences in different periods of ontogeny $[11,15]$.

In addition, there has been an increasing number of epidemiological studies recently revealing gender differences in the prevalence and progression of respiratory diseases [5]. In particular, adolescence young men have an increased exacerbation and greater incidence of asthma than young women, and in adolescence and adulthood this tendency is more pronounced in women. In chronic obstructive pulmonary disease (COPD), a disease that has historically been considered a men's disease, the mortality rate among women is now higher than among men [19]. COPD in women differs from men in phenotype, symptomatology and comorbidities. Women are more likely to develop chronic bronchitis, have more severe shortness of breath and comorbidity about diseases of the nervous system, in particular depression [21]. Compared to men, COPD in women revealed less airway obstruction, but more 
serious impairment in gas transmission mechanisms. Parenchymal lesions in assessing lung diffusion capacity had a higher ratio of one-second forced expiratory volume (\% of predicted) in women than in men [13].

Gender differences in the prevalence and progression of cystic fibrosis have been established [22]. In women, this genetic disease has worse effects (leading to a reduction in life expectancy) than in men, especially in response to Pseudomonas aeruginosa respiratory infections. Women also become colonized by certain common agents of cystic fibrosis earlier than men [20].

The rationale for such gender inequalities in respiratory diseases is only beginning to unfold, and further exploration of the mechanisms that will help develop treatment options for more effective individualized patient care. One of the ways of solving this problem is the study of spirometric parameters $[6,7,12,14]$ in practically healthy individuals of different sex of a separate ontogeny period in order to establish age and sex norms [1].

The aim of this work is to establish the sex characteristics of spirographic normative indices in practically healthy young men and young women within the juvenile ontogeny period.

\section{Materials and methods}

The materials of the study were obtained from the data bank of the research center of National Pirogov Memorial Medical University, Vinnytsya. Spirographic examination of 109 young women of the ontogeny adolescence was performed, including: 17-year-olds - 29; 18-year-olds - 27; 19-year-olds 25; 20-year-olds - 28 people and 124 young men, including: 17-year-olds - 28; 18-year-olds - 37; 19-year-olds - 27; 20 year-olds - 32 people. Spirographic examination was performed according to the method of the American Association of Pulmonologists [2] on the device Medgraphics Pulmonary Function System 1070 series. The following spirographic parameters were investigated: FVC - forced vital capacity; SVC - vital lung capacity; FIVC - forced lung capacity for inhalation; MVV - maximal voluntary ventilation; FEF $25 \%$ forced expiratory flow, respectively, of $25 \%$ of the forced life capacity; FEF $50 \%$ - forced expiratory flow of $50 \%$ of forced life, respectively; FEF $75 \%$ - forced expiratory flow, respectively, of $75 \%$ of the forced life capacity; FEF $75-85 \%$ - forced expiratory flow $(75 \%$ to $85 \%$ exhaled expiratory vital capacity, respectively); FEF 25-75 \% - average expiratory flow; FEF MAX - maximum peak expiratory flow; IC - inspiratory capacity; ERV - expiratory reserve volume; FIF $50 \%$ - forced inspiratory flow, which is $50 \%$ of the exhale from the forced life capacity; FEV1 - one-second forced expiratory volume; FEV1/FVC is the ratio of one-second forced expiratory volume to the forced vital capacity (Tiffno Index). The results obtained were analyzed using the Statistica 5.5 licensing program, using nonparametric methods of estimating indicators.

\section{Results}

We found that the vital capacity index in 17-year-old young men was significantly greater than in 17 -year-old young women $(p<0.001)$, in 18-year-old young men significantly higher than in 18-year-old young women $(p<0.001)$, in 19year-old young men were significantly larger than 19-yearold young women $(p<0.001)$ and 20 -year-old young men were significantly larger than 20-year-old young women $(p<0.001)$. The value of the vital capacity index is significantly higher in the general group of young men than in the general group of young women $(p<0.001)$, which logically follows from the previous regularities (Table 1). The rate of forced vital capacity in young men is significantly higher (in all cases $p<0.001$ ) than in young women. We found that the forced inspiratory flow in 17-year-old young men was significantly higher than in 17-year-old young women $(p<0.01)$, in 18year-old young men significantly higher than in 18-year-old young women $(p<0.001)$, in 19-year-old young men were significantly larger than 19-year-old young women $(p<0.01)$ and in 20-year-old young men were significantly larger than 20 -year-old young women $(p<0.001)$. The magnitude of the forced inspiration flow was significantly higher in the general group of young men than in the general group of young women $(p<0.001)$ (see Table 1).

It was found that the maximal voluntary ventilation rate in young men was significantly higher (in all cases $p<0.001$ ) than in young women in all ages during the adolescent ontogeny period and in the general comparison groups. The expiratory volume rate, which is $25 \%$ of exhalation from the forced vital capacity, respectively, in 17-year-old and 18year-old young men was significantly higher than in 17-yearold and 18-year-old young women (in both cases, $p<0.001$ ), in 19-year and 20-year-old young men were significantly larger than young women of the corresponding calendar age (in both cases $p<0.01$ ) in the general group of young men than in the general group of young women $(p<0.001)$. It was found that the expiratory volume rate, which is $50 \%$ of exhalation from the forced vital capacity in 17-year-old young men was significantly higher than in 17-year-old young women $(p<0.001)$, in 18-year-old young men significantly higher than in 18-year-old young women $(p<0.001)$, in the general group of young men significantly higher than in the general group of young women $(p<0.001)$. The expiratory volume rate, which is $75 \%$ of exhalation from the forced vital capacity was significantly higher in the general group of young men than in the general group of young women $(p<0.001)$ and in 17-year-old young men than in 17-year-old young women $(p<0.01)$, in 18-year-old young men than in 18 -year-old young women $(p<0.001)$. We found that the expiratory volume rate, respectively, from $75 \%$ to $85 \%$ of exhaled expedited life capacity in 17-year-old young men is greater than in 17-year-old young women $(p<0.01)$, in 18year-old young men is greater than in 18-year-old young women $(p<0.05)$, in the general group of young men than in the general group of young women $(p<0.01)$ (see Table 1).

The mean expiratory flow rate in 17-year-old young men was significantly higher than in 17-year-old young women $(p<0.001)$ and in 18-year-old young men than in 18-year-old young women $(p<0.001)$. We found that the value of this 
Kyrychenko Yu. V., Sarafinyuk L. A., Sarafinyuk P. V., Romanenko O. I., Lischyshyn G. B.

Table 1. Sexual dimorphism of spirographic indices in yuong men and yuong women $(\mathrm{M} \pm \sigma)$.

\begin{tabular}{|c|c|c|c|}
\hline Indicators & Age groups & Young women & Young men \\
\hline \multirow{5}{*}{ SVC (I) } & 17 & $3.980 \pm 0.762$ & $5.384 \pm 0.701^{* * *}$ \\
\hline & 18 & $4.011 \pm 0.536$ & $5.473 \pm 0.805^{\star \star \star}$ \\
\hline & 19 & $4.130 \pm 0.628$ & $5.561 \pm 0.712^{\star \star \star}$ \\
\hline & 20 & $4.305 \pm 0.675$ & $5.809 \pm 0.916^{\star * *}$ \\
\hline & Total & $4.039 \pm 0.676$ & $5.665 \pm 0.825^{\star \star \star}$ \\
\hline \multirow{5}{*}{ FVC (I) } & 17 & $3.715 \pm 0.619$ & $5.116 \pm 0.994^{\star \star \star}$ \\
\hline & 18 & $3.723 \pm 0.696$ & $5.307 \pm 1.130^{* * *}$ \\
\hline & 19 & $3.895 \pm 0.674$ & $5.200 \pm 0.865^{\star * \star}$ \\
\hline & 20 & $4.005 \pm 0.734$ & $5.402 \pm 1.119^{\star \star \star}$ \\
\hline & Total & $3.767 \pm 0.665$ & $5.417 \pm 1.044^{\star \star *}$ \\
\hline \multirow{5}{*}{ FIVC (I) } & 17 & $2.685 \pm 0.672$ & $3.608 \pm 1.147^{* *}$ \\
\hline & 18 & $2.761 \pm 0.788$ & $3.702 \pm 1.124^{\star * *}$ \\
\hline & 19 & $2.921 \pm 0.633$ & $3.704 \pm 1.024^{* *}$ \\
\hline & 20 & $2.462 \pm 0.663$ & $3.677 \pm 1.134^{\star * *}$ \\
\hline & Total & $2.686 \pm 0.715$ & $3.682 \pm 1.065^{\star \star *}$ \\
\hline \multirow{5}{*}{ MVV (I/m) } & 17 & $100.0 \pm 19.9$ & $153.3 \pm 38.7^{\star \star *}$ \\
\hline & 18 & $105.9 \pm 21.3$ & $181.5 \pm 34.1^{* \star *}$ \\
\hline & 19 & $104.0 \pm 28.3$ & $176.5 \pm 32.3^{* \star *}$ \\
\hline & 20 & $121.8 \pm 23.5$ & $189.9 \pm 34.0^{\star \star *}$ \\
\hline & Total & $106.4 \pm 24.0$ & $180.8 \pm 37.3^{\star \star *}$ \\
\hline \multirow{5}{*}{ FEF $25 \%(\mathrm{l} / \mathrm{s})$} & 17 & $5.775 \pm 0.847$ & $7.985 \pm 1.789^{\star \star \star}$ \\
\hline & 18 & $5.348 \pm 1.181$ & $8.780 \pm 2.012^{\star \star \star}$ \\
\hline & 19 & $6.285 \pm 1.299$ & $8.007 \pm 2.417^{\star *}$ \\
\hline & 20 & $6.906 \pm 1.544$ & $8.647 \pm 2.139^{* *}$ \\
\hline & Total & $6.047 \pm 1.367$ & $8.566 \pm 2.073^{\star \star *}$ \\
\hline \multirow{5}{*}{ FEF $50 \%(\mathrm{l} / \mathrm{s})$} & 17 & $4.213 \pm 0.956$ & $5.654 \pm 1.270^{\text {***}}$ \\
\hline & 18 & $3.685 \pm 0.986$ & $6.242 \pm 1.706^{\star \star *}$ \\
\hline & 19 & $4.438 \pm 1.332$ & $5.156 \pm 1.822$ \\
\hline & 20 & $5.030 \pm 1.344$ & $5.746 \pm 1.885$ \\
\hline & Total & $4.342 \pm 1.202$ & $5.787 \pm 1.675^{\star \star *}$ \\
\hline \multirow{5}{*}{ FEF $75 \%(1 / s)$} & 17 & $2.203 \pm 0.701$ & $2.963 \pm 1.038^{* *}$ \\
\hline & 18 & $2.052 \pm 0.724$ & $2.985 \pm 1.031^{\star \star *}$ \\
\hline & 19 & $2.355 \pm 0.856$ & $2.609 \pm 1.120$ \\
\hline & 20 & $2.678 \pm 0.704$ & $2.954 \pm 1.250$ \\
\hline & Total & $2.334 \pm 0.765$ & $2.902 \pm 1.084^{\star \star \star}$ \\
\hline \multirow{5}{*}{$\begin{array}{c}\text { FEF } 75-85 \% \\
(1 / s)\end{array}$} & 17 & $1.675 \pm 0.619$ & $2.342 \pm 0.902^{* *}$ \\
\hline & 18 & $1.684 \pm 0.604$ & $2.245 \pm 0.871^{*}$ \\
\hline & 19 & $1.870 \pm 0.758$ & $1.968 \pm 0.927$ \\
\hline & 20 & $2.107 \pm 0.697$ & $2.245 \pm 1.093$ \\
\hline & Total & $1.859 \pm 0.691$ & $2.218 \pm 0.946^{* *}$ \\
\hline
\end{tabular}

indicator is greater in the general group of young men than in the general group of young women $(p<0.001)$. Indicators of maximum peak expiratory flow and inspiratory capacity in young men of the general group and each calendar year
Continuation of table 1.

\begin{tabular}{|c|c|c|c|}
\hline Indicators & Age groups & Young women & Young men \\
\hline \multirow{5}{*}{$\begin{array}{l}\text { FEF } 25-75 \% \\
(\mathrm{l} / \mathrm{s})\end{array}$} & 17 & $3.701 \pm 0.982$ & $5.028 \pm 1.235^{\star \star \star}$ \\
\hline & 18 & $3.349 \pm 0.953$ & $5.486 \pm 1.394^{\star \star *}$ \\
\hline & 19 & $3.997 \pm 1.173$ & $4.692 \pm 1.663$ \\
\hline & 20 & $4.500 \pm 1.161$ & $5.173 \pm 1.618$ \\
\hline & Total & $3.864 \pm 1.126$ & $5.153 \pm 1.463^{\text {***}}$ \\
\hline \multirow{5}{*}{ FEF MAX (I/s) } & 17 & $6.636 \pm 1.072$ & $9.676 \pm 2.403^{\text {***}}$ \\
\hline & 18 & $6.233 \pm 1.688$ & $10.49 \pm 2.29^{\star * *}$ \\
\hline & 19 & $7.173 \pm 1.661$ & $10.47 \pm 2.09^{* * *}$ \\
\hline & 20 & $7.323 \pm 1.918$ & $10.99 \pm 2.26^{\star * *}$ \\
\hline & Total & $6.778 \pm 1.604$ & $10.60 \pm 2.31^{\text {***}}$ \\
\hline \multirow{5}{*}{ IC (I) } & 17 & $2.727 \pm 0.645$ & $3.456 \pm 0.644^{* * *}$ \\
\hline & 18 & $2.687 \pm 0.549$ & $3.490 \pm 0.558^{* * *}$ \\
\hline & 19 & $2.552 \pm 0.403$ & $3.468 \pm 0.477^{\star \star \star}$ \\
\hline & 20 & $2.627 \pm 0.387$ & $3.711 \pm 0.760^{\text {***}}$ \\
\hline & Total & $2.627 \pm 0.494$ & $3.588 \pm 0.655^{\star \star *}$ \\
\hline \multirow{5}{*}{ ERV (I) } & 17 & $1.251 \pm 0.291$ & $1.926 \pm 0.484^{\star * *}$ \\
\hline & 18 & $1.325 \pm 0.286$ & $1.983 \pm 0.680^{\text {***}}$ \\
\hline & 19 & $1.578 \pm 0.427$ & $2.094 \pm 0.680^{\star *}$ \\
\hline & 20 & $1.676 \pm 0.563$ & $2.098 \pm 0.649^{* *}$ \\
\hline & Total & $1.411 \pm 0.458$ & $2.076 \pm 0.622^{\star \star *}$ \\
\hline \multirow{5}{*}{ FIF $50 \%(\mathrm{l} / \mathrm{s})$} & 17 & $2.265 \pm 0.856$ & $2.911 \pm 1.466$ \\
\hline & 18 & $2.374 \pm 1.000$ & $2.935 \pm 1.105^{*}$ \\
\hline & 19 & $2.412 \pm 0.812$ & $2.871 \pm 1.072$ \\
\hline & 20 & $2.557 \pm 0.869$ & $2.991 \pm 1.403$ \\
\hline & Total & $2.374 \pm 0.822$ & $2.979 \pm 1.240^{* \star *}$ \\
\hline \multirow{5}{*}{ FEV1 (I) } & 17 & $3.214 \pm 0.510$ & $4.428 \pm 0.844^{* \star *}$ \\
\hline & 18 & $3.204 \pm 0.604$ & $4.598 \pm 0.975^{\star \star *}$ \\
\hline & 19 & $3.432 \pm 0.688$ & $4.344 \pm 0.841^{\star \star \star}$ \\
\hline & 20 & $3.551 \pm 0.682$ & $4.720 \pm 0.885^{\star \star \star}$ \\
\hline & Total & $3.305 \pm 0.619$ & $4.641 \pm 0.889^{\text {***}}$ \\
\hline \multirow{5}{*}{ FEV1/FVC (\%) } & 17 & $86.85 \pm 7.14$ & $86.47 \pm 6.32$ \\
\hline & 18 & $86.81 \pm 7.68$ & $86.39 \pm 5.20$ \\
\hline & 19 & $87.82 \pm 7.46$ & $83.53 \pm 8.39$ \\
\hline & 20 & $87.68 \pm 10.87^{*}$ & $85.22 \pm 5.32$ \\
\hline & Total & $87.72 \pm 8.26^{\star *}$ & $85.21 \pm 6.45$ \\
\hline
\end{tabular}

Notes: ${ }^{* \star *}$ - indicator of statistical significance of sex differences if $p<0.001 ;{ }^{* *}$ - indicator of statistical significance of sex differences if $p<0.01$; * - indicator of statistical significance of sex differences if $p<0.05$.

were significantly higher compared to the corresponding years of ontogeny in young women (in all cases, $p<0.001$ ) (see Table 1).

It was found that the residual expiratory volume rate in 17-year-old young men was significantly higher than in 17year-old young women $(p<0.001)$, in 18-year-old young men significantly higher than in 18-year-old young women 
$(p<0.001)$, in 19-year-old young men were significantly larger than 19-year-old young women $(p<0.01)$ and 20 -year-old young men were significantly larger than 20 -year-old young women $(p<0.01)$. The value of the residual expiratory volume was significantly higher in the general group of young men than in the general group of young women $(p<0.001)$, which is quite clear when considering the previous patterns.

The forced expiratory volume rate, which is $50 \%$ of exhalation from the forced vital capacity of only 18-year-old young men is significantly greater than in 18-year-old adolescent young women of ontogeny period $(p<0.05)$, in the general group of young men the value of this indicator is greater than in the general group of young women $(p<0.001)$.

It was found that the one-second forced expiratory volume of young men in all comparison groups $(p<0.001)$ was significantly higher than that of young women.

We found that in the general group of young women the value of the Tiffno index was significantly higher than in the general group of young men $(p<0.01)$ and in 20 -year-old young women greater than in 20-year-old young men $(p<0.05)$ (see Table 1).

\section{Discussion}

In most scientific studies, there are significant differences in spirometric parameters between male and female $[3,4$, $10]$. Analyzing the sex characteristics of spirometry indices within the adolescent ontogeny period, we find that in all cases they are of greater importance in male than female, except for the Tiffno index. We found that the index of vital capacity of lungs in young men each calendar year (at 17 years by $35.27 \%$, at $18-36.45 \%$, at $19-34.64 \%$, at $20-$ $34.93 \%$ ) and the general group (by $40.25 \%$ ) significantly higher compared to the corresponding years of ontogeny in young women. V. A. Melnyk and S. N. Melnyk [15] found that the rates of vital capacity of the lungs were higher in young men compared to young women in all age groups, and it was found that with age within the adolescent ontogeny, this indicator increases more rapidly in representatives male. This pattern is confirmed by the results obtained in our study, within the adolescent ontogeny period.

The most significant gender differences in the magnitude of the forced vital capacity index were established at the age of 18 (it is $42.57 \%$ higher for young men than for young women); in 17-year-old young men this indicator is $37.71 \%$ higher than in young women; in 19-year-olds - by $33.50 \%$; in 20 -year-olds - by $34.88 \%$; in the general group of young men, compared with the general group of young women by $43.80 \%$. We found that the forced expiratory lung capacity of adolescents in each calendar year is significantly higher than the corresponding years of ontogeny in young women: in the 17 and 18 years, an increase is observed in the range of $34 \%$, in 19 years found the smallest gender difference (only $26.80 \%$ this indicator is higher in young men), in 20 years - the highest (by $48.94 \%$ ). The maximum voluntary ventilation rate is significantly higher for young men than for young women in all ages, particularly for 17 -year-old young men by $53.30 \%$ higher than for 17-year-old young women, in 18.3-year-old young men by $71.38 \%$, in 19-year-old young men - by 69.71 $\%$, in 20-year-old young men - by $55.91 \%$; in the general comparison groups, the gender difference is $69.92 \%$.

It was found that the expiratory volume rate, respectively, of $25 \%$ of the forced vital capacity was significantly higher in young men each calendar year compared to the corresponding years of ontogeny in young women. In 17 years the sex difference of this indicator is $38.26 \%$, in 18 $64.17 \%$, in $19-27.39 \%$, in $20-25.20 \%$, in the general group $-41.65 \%$. It was found that the expiratory volume rate of $50 \%$ of the forced life capacity of young men, respectively, compared to young women, was significantly higher only in the first half of the ontogeny adolescent period (at 17 by $34.20 \%$, at 18 by $64.17 \%$ ). As with the previous spirometric index, the expiratory volume rate, respectively, in $75 \%$ of the forced life capacity has significant gender differences only in 17-year-olds ( $34.49 \%$ higher in young men) and 18-yearolds (45.46\% higher in young men) persons of adolescent ontogeny.

The expiratory volume rate, respectively, from $75 \%$ to $85 \%$ of exhaled expiratory life capacity in 17-year-old young men was significantly higher $(39.82 \%)$ than in 17 -year-old young women, 18-year-old young men higher (33.31\%) than their peers young women. In the first half of the adolescent ontogenesis, the mean expiratory flow rate was significantly higher in males compared to females (by $39.82 \%$ at 17 , $33.31 \%$ at 18 ).

The maximum peak expiratory flow rate in 17-year-old young men is $53.95 \%$ higher than in 17-year-old young women, in 18-year-old young men by $49.66 \%$, in 19-yearold young men by $32.70 \%$ and in 20 -year-olds young men are $25.17 \%$ higher than in young women of the same age.

It was found that the rate of inspiratory capacity in young men is significantly higher than that of young women in all ages during adolescence (at 17 years by $26.73 \%$, at 18 $29.88 \%$, at $19-35.89 \%$, at $20-41.26 \%$ ). The value of this indicator is higher in the general group of young men compared to the general group of young women (by 36.58 $\%)$, which confirms the age differences we have established when comparing individual groups of young men and young women. We found that the residual exhalation volume of 17year-old young men was greater than that of 17 -year-old young women (by $53.95 \%$ ), that of 18 -year-old young men was greater than that of 18 -year-old young women (by $49.66 \%$ ), 19 -year-old young men - than 19-year-old young women (32.70\%), 20-year-old young men - less than 20-year-old young women $(25.17 \%)$. Thus, we found that this spirometric indicator in young men each calendar year is significantly higher than in young women, and, the most significant manifestations of sexual dimorphism are observed in the first years of adolescent ontogeny. The rate of forced inspiratory flow, which is $50 \%$ of exhalation from the forced life capacity only in 18-year-old young men is significantly higher (by 23.63 $\%)$ than in 18-year-old young women. In the general group of young men the value of this indicator is much higher (by 
$25.48 \%$ ) than in the general group of young women.

It is established that the indicator of one-second forced exhalation volume in young men of every calendar year is significantly higher compared to the corresponding years of ontogeny in young women (in 17 years by $37.77 \%$, in 18 $43.50 \%$, in $19-26.57 \%$, in $20-32.92 \%$ ). The one-second expiratory volume is accordingly $40.42 \%$ higher in the general young men group than in the young women group, which clearly follows from the previous patterns.

The only spirometric indicator that is significantly higher for young women than for young men is the Tiffno Index. This figure is significantly higher in 20-year-old young women than in 20-year-old young men, and in the general group of young women, the Tiffno index is significantly greater than in the general group of young men.

The sex differences we found in the magnitude of spirometric parameters can be explained by the significant somatometric differences between the male and female body. Indeed, it is the complex of anthropometric and somatotypological features that determines the features of morpho-functional indicators [23]. Recent scientific studies reveal the relationship between individual indicators of the external structure of the body and those of external respiration [22]. Relationships of fat mass with indicators of pulmonary function for both age and sex were detected. On the other hand, total non-fat mass showed a positive association with

\section{References}

[1] Alfrayh, A., Khoja, T., Alhusain, K., Alshehri, S., Gad, A., \& Madani, M. (2014). FEV1 and FVC pulmonary function reference values among 6-18-year-old children: a multi-centre study in Saudi Arabia. East Mediterr Health J., 20(7), 424430.

[2] American Thoracic Society, Standardization of Spirometry 1994 Update (1995). Am.J.Respir.Crit.Care Med. 152, 1107-1136.

[3] Asif, M., Mustafa, G., Aslam, M., \&Altaf, S. (2017). Predictors of pulmonary function test values for Pakistani children, aged 514 years. Age, 10, 2-41. doi: 10.1016/j.resp.2017.10.009

[4] Broström, E., Jõgi, R., Gislason, T., Benediktsdottir, B., Burney, P. G., \& Janson, C. (2018). The prevalence of chronic airflow obstruction in three cities in the Nordic-Baltic region. Respiratory medicine, 143, 8-13. doi: 10.1016/ j.rmed.2018.08.007

[5] Carrasco-Garrido, P., de Miguel-Diez, J., Rejas-Gutierrez, J., Martin-Centeno, A., Gobartt-Vázquez, E., Hernandez-Barrera, V., ... Jimenez-Garcia, R. (2009). Characteristics of chronic obstructive pulmonary disease in Spain from a gender perspective. BMC pulmonary medicine, 9(1), 2. doi: 10.1186/ 1471-2466-9-2

[6] Chhabra, S. K., Kumar, R., \& Mittal, V. (2016). Prediction equations for spirometry for children from northern India. Indian Pediatr., 53(9), 781-785.

[7] Global Initiative for Asthma. Global strategy for the diagnosis and prevention. Global Initiative for Asthma (2018). www.ginasthma.org

[8] Gnenna, W. O. (2014). Features of linear dimensions of the thyroid gland in practically healthy men and women of the division of the first mature age. Bulletin of Morphology, 2 (20), 457-460.

[9] Holguera, R. M., Nieves, A. I. T., Torres, R. R., \&Alonso, M. C. indicators of pulmonary function [17]. Studies have been conducted regarding the association of fat mass index and the degree of obesity with pulmonary function in individuals aged 18 to 22 years. In the studies of Holguera R. M. and others $[9,10]$ found that in men the muscular mass of the lower extremities is most closely related to spirometric parameters, in women the muscular mass of the trunk has the highest correlations. The linear dependence of spirometry on body length and body weight in adolescence has been established in studies by Asif M. et al. [3]. Thus, the total body size and size of body fat, the morpho-functional state of the muscles of the trunk and lower extremity, which have the most pronounced sex differences, are related to indicators of external respiration.

\section{Conclusions}

1. It has been found that spirometric indices within the juvenile ontogeny period are significantly higher in males $(p<0.05-0.001)$ than in females, except for the Tiffno index, which is higher for young women in the general group $(p<0.01)$ and 20 years $(p<0.05)$.

2. The most significant sex differences in the majority of spirometric parameters (forced vital capacity, maximal voluntary ventilation, forced expiratory volume, expiratory flows, expiratory residual volume, one-second forced expiratory volume) were determined at 18 years of age.

(2018). The effects of truncal adiposity in forced spirometry: Sex differences. Respiratory physiology \& neurobiology, 247, 167-173.

[10] Holguera, R. M., Nieves, A. I. T., Torres, R. R., \& Alonso, M. C. (2017). Relationship of Muscle Mass Determined by DEXA with Spirometric Results in Healthy Individuals. Archivos de Bronconeumologia (English Edition), 53(7), 375-380. doi: 10.1016/j.arbres.2016.11.020

[11] Hoo, A. F., Dezateux, C., Hanrahan, J. P., Cole, T. J., Tepper, R. S., \& Stocks, J. (2002). Sex-specific prediction equations for Vmax (FRC) in infancy: a multicenter collaborative study. Am. J. Respir. Crit .Care Med, 15(8), 1084-1092. doi: 10.1164/ ajrccm.165.8.2103035

[12] Imad, H., \& Yasir, G., (2015). Epidemiological and clinical characteristics, spirometric parameters and response to budesonide/formoterol in patients attending an asthma clinic: an experience in a developing country. Pan. Afr. Med. J., 21(1), 154. doi: 10.11604/pamj.2015.21.154.5404

[13] Laitinen, T., Hodgson, U., Kupiainen, H., Tammilehto, L., Haahtela, T., Kilpel?inen, M., ... Kinnula, V. L. (2009). Real-world clinical data identifies gender-related profiles in chronic obstructive pulmonary disease. COPD: Journal of Chronic Obstructive Pulmonary Disease, 6(4), 256-262. doi: 10.1080/ 15412550903051799

[14] Luize, A. P., Menezes, A. M. B., Perez-Padilla, R., Muiño, A., López, M. V., Valdivia, G., ... Nascimento, O. A. (2014). Assessment of five different guideline indication criteria for spirometry, including modified GOLD criteria, in order to detect COPD: data from 5,315 subjects in the PLATINO study. NPJ primary care respiratory medicine, 24,14075 . doi: $10.1038 /$ npjpcrm. 2014.75

[15] Melnik, V. A., Melnik, S. N. (2018). Constitutional features of 
the age dynamics of functional indicators of the cardiorespiratory system of urban schoolchildren. Bulletin of TVSU. Series "Biology and Ecology". 1. 7-20.

[16] Moroz, V. M., Sarafinyuk, L. A., \& Gunas, I. V. (2008). Age and sex characteristics of central hemodynamics in adolescence. Biomedical and biosocial anthropology, 10, 92-97.

[17] Oliveira, P. D., Wehrmeister, F. C., Perez-Padilla, R., Gonçalves, H., Assuncao, M. C. F., Horta, B. L., ... \& Menezes, A. M. B. (2016). Relationship between body composition and pulmonary function in early adult life: a cross-sectional analysis nested in two birth cohort studies. PloS one, 11(9), e0163428. doi: 10.1371/journal.pone.0163428

[18] Prokopenko, S. V., \& Melnyk, M. P. (2014). Age and sex characteristics of sonographic parameters of the liver in men and women of Podillya. World of Medicine and Biology, 4 (46), 43-46.

[19] Raghavan, D., \& Jain, R. (2016). Increasing awareness of sex differences in airway diseases. Respirology, 21(3), 449-459. doi: 10.1111/resp.12702

[20] Raghavan, D., Gao, A., Ahn, C, Kaza, V., Finklea, J., Torres, F., \& Jain, R. (2016). Lung transplantation and gender effects on survival of recipients with cystic fibrosis. J Heart Lung Transplant, 35(12), 1487-1496. doi: 10.1016/j.healun.2016.06.013

[21] Raghavan, D., Varkey, A., \& Bartter, T. (2017). Chronic obstructive pulmonary disease: the impact of gender. Curr Opin Pulm Med., 23(2), 117-123. doi: 10.1097/ MCP. 0000000000000353

[22] Sarafinyuk, L. A., Gudzevich, L. S., Kaminska, N. A., \& Kuhar, I. D. (2004). Relationship of anthropometric parameters of the body with indicators of external respiration in healthy urban adolescents. Reports of Morphology, 10 (2), 395-398.

[23] Yakusheva, Y. I., Sarafinyuk, L. A., \& Kyrychenko, Yu. V. (2015). Relationships of reocardiographic parameters of central hemodynamics with constitutional indices in volleyball players of different roles. World of Medicine and Biology, 4 (53), 96-102.

\section{СТАТЕВІ ОСОБЛИВОСТІ СПІРОМЕТРИЧНИХ ПОКАЗНИКІВ У ЮНАЦЬКОМУ ПЕРІОДІ ОНТОГЕНЕЗУ}

\section{Кириченко Ю. В., Сарафинюк Л. А., Сарафинюк П. В., Романенко О. І., Лісчишин Г. В.}

Фактор статевого диморфізму має домінантне значення у онтогенетичному формуванні різних органів та систем, зокрема органів дихання, морфо-функціональні показники яких мають значні статеві відмінності. Мета роботи - встановити статеві особливості нормативних показників спірографії у практично здорових юнаків і дівчат у межах юнацького періоду онтогенезу. Проведено спірографрічне обстеження 109 дівчат юнацького періоду онтогенезу, з них: 17-річних - 29; 18-річних - 27; 19-річних - 25; 20-річних - 28 осіб та 124 хлопців юнацького віку серед яких: 17-річних - 28; 18-річних - 37; 19-річних - 27; 20-річних - 32 особи. Спірографрічне дослідження проводили за методикою Американської асоціації пульмонологів (1995) на апараmi Medgraphics Pulmonary Function System 1070 series. Аналіз отриманих результатів проведений за допомогою ліцензійної програми "Statistica 5.5" з використанням непараметричних методів оцінки показників. Встановлено, що показники життєвої ємності легень, форсованої життєвої ємності, форсованої ємності легень на вдиху, максимальної довільної вентиляції, об'ємної швидкості видиху відповідно у 25\% від форсованої життєвої ємності, максимального пікового потоку видиху, ємності вдиху, залишкового об'єму видиху та односекундного об'єму фрорсованого видиху в юнаків кожного календарного року та загальної групи достовірно більші у порівнянні з відповідними роками онтогенезу у дівчат. Єдиним спірометричним показником, який у дівчат достовірно більший, ніж у юнаків, є індекс Тіффно. Виявлені статеві відмінності у величині спірометричних показників можна пояснити значними соматометричними відмінностями чоловічого та жіночого тіла. На основі отриманих результатів можна зробити висновок, що переважна більшість спірометричних показників у юнаків в усі календарні періоди юнацького віку має більші значення, ніж у дівчат. Найсуттєвіші статеві відмінності у величині більшості спірометричних показників визначені у 18-річних осіб.

ключові слова: спірометрія, спірометричні показники, юнаки, дівчата, статевий диморфізм.

\section{ПОЛОВЫЕ ОСОБЕННОСТИ СПИРОМЕТРИЧЕСКИХ ПОКАЗАТЕЛЕЙ В ЮНОШЕСКОМ ПЕРИОДЕ ОНТОГЕНЕЗА \\ Кириченко Ю. В., Сарафинюк Л. А., Сарафинюк П. В., Романенко А. И., Лисчишин Г. В.}

Фактор полового диморфизма имеет доминантное значение в онтогенетическом фрормировании различных органов и систем, в том числе органов дыхания, морфо-фрункциональные показатели которых имеют значительные половые различия. Цель работы - установить половые особенности нормативных показателей спирографии у практически здоровых юношей и девушек в пределах юношеского периода онтогенеза. Проведено спирографическое обследование 109 девушек юношеского периода онтогенеза, из них: 17-летних - 29; 18-летних - 27; 19-летних - 25; 20-летних - 28 человек и 124 ребят юношеского возраста среди которых: 17-летних - 28; 18-летних - 37; 19-летних - 27; 20-летних - 32 человека. Спирографическое исследования проводили по методике Американской ассоциации пульмонологов (1995) на аппарате Medgraphics Pulmonary Function System 1070 series. Анализ полученных результатов проведен с помощью лицензионной программы "Statistica 5.5" с использованием непараметрических методов оценки показателей. Установлено, что показатели жизненной емкости легких, форсированной жизненной емкости, форсированной емкости легких на вдохе, максимальной произвольной вентиляции, объемной скорости выдоха соответственно в 25\% от форсированной жизненной емкости, максимального пикового потока выдоха, емкости вдоха, остаточного объема выдоха и односекундного объема форсированного выдоха у юношей каждого календарного года и общей группы достоверно больще по сравнению с соответствующими годами онтогенеза у девушек. Единственным спирометрическим показателем, который у девушек достоверно больше, чем у юношей, является индекс Тифрфно. Выявленные половые различия в величине спирометрических показателей можно объяснить значительными соматометрическими различиями мужского и женского тела. На основе полученных результатов можно сделать вывод, что подавляющее большинство спирометрических показателей у юношей во все календарные периоды юношеского возраста имеет большие значения, чем у девушек. Существенные половые различия в величине большинства спирометрических показателей определены у 18-летних лиц.

Ключевые слова: спирометрия, спирометрические показатели, юноши, девушки, половой диморфизм. 